\title{
Hafnium isotopes in zircons document the gradual onset of mobile-lid tectonics
}

\author{
A.M. Bauer ${ }^{1,2^{*}}$ and J.R. Reimink ${ }^{3,4^{*}}$, T. Chacko ${ }^{5}$, \\ B.J. Foley ${ }^{3}$, S.B. Shirey ${ }^{4}$, D.G. Pearson ${ }^{5}$
}

Abstract

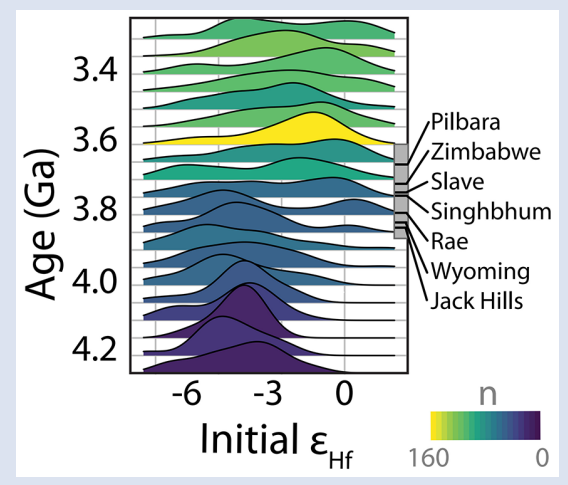

doi: 10.7185/geochemlet.2015

Received 2 December 2019 | Accepted 25 March 2020 | Published 16 April 2020

\section{Introduction}

On the modern Earth, continental crust is mostly generated at convergent plate margins through subduction-driven mantle melting. Due to the limited extent of the early rock record, it remains unclear whether a similar process was operative throughout Earth history or if there were major changes in the dominant mechanisms of continental crust production over time. On the basis of geological data and theoretical models, some workers have proposed that the earliest continental crust formed by remelting of long-lived mafic crust, either in local oceanic plateaus or in a global stagnant lid (Kemp et al., 2010; Reimink et al., 2014; van Kranendonk et al., 2015). Determining whether protocrustal residence time varied regionally will shed light on the tectonic processes responsible for early crust production. Specifically, a uniformitarian view of continental crust production mechanisms is predicated on little change in the residence time of protocrust, whereas a non-uniformitarian view permits major changes that, in turn, would imply a transition in Earth's tectonic regime. A stagnant lid can only recycle mafic protocrust through volcanic burial, while a "mobile-lid" regime, with active subduction-possibly in a different style than modern plate tectonics - can rapidly recycle mafic crust and transport surface-derived volatiles into the mantle.

Long-lived radiogenic isotope systems are powerful tracers of crustal evolution as they track crustal residence times and changes in magma source. Zircon is particularly useful because it preserves the original Hf isotope composition of the magma from which it is derived and, through the $\mathrm{U}-\mathrm{Pb}$ decay system, precise information on the time of magma crystallisation. Crust has a lower Lu/Hf than residual mantle and therefore accumulates less radiogenic ${ }^{176} \mathrm{Hf}$ relative to the mantle, which is reflected in the resulting lower $\varepsilon_{\mathrm{Hf}}$ signature. Arrays of decreasing $\varepsilon_{\mathrm{Hf}}$ values with time suggest repeated reworking of pre-existing crust. Alternatively, shifts in Hf isotopic compositions reflect contributions from other sources such as the mantle, which often coincide with changes in crust production mechanisms.

The Hadean Earth may have been dominated by a ubiquitous mafic protocrustal lid (Kamber, 2007; Shirey et al., 2008), but this view is based on only a few locales and therefore its global applicability has remained speculative. An extensive dataset is now available to assess the nature of the sources of Hadean and Archean magmas on a global scale. We compile the global Hf isotope record of 4.3-3.0 Ga zircons (including

\footnotetext{
1. Department of Geoscience, University of Wisconsin-Madison, Madison, WI, USA

. Department of Geology and Geophysics, Yale University, New Haven, CT, USA

3. Department of Geosciences, The Pennsylvania State University, State College, PA, USA

Earth and Planets Laboratory, Carnegie Institution for Science, DC, USA

5. Department of Earth \& Atmospheric Sciences, University of Alberta, Edmonton, Alberta, Canada

Corresponding author (email: annie.bauer@wisc.edu, jreimink@psu.edu)

The two corresponding authors contributed equally to this work.
} 
magmatic, xenocrystic, and detrital zircons; references in Methods, see Supplementary Information) of eight different Archean cratons. We compare the general $\varepsilon_{\mathrm{Hf}}$-time evolution reflected in that dataset with a comparable dataset for the 4.02-3.4 Ga Acasta Gneiss Complex (AGC) of the Slave craton of Canada, a locale where zircon Hf isotope data is directly linked to parental whole rock geochemistry spanning 600 Myr of crust evolution. This comparison is necessitated by the nature of the extant data from other cratons, which are largely comprised of detrital zircons with only indirect links to their parental igneous rocks.

\section{The Global Hf Isotope Dataset}

The relatively well-characterised meta-igneous rocks of the AGC represent the earliest felsic rock record on Earth. We have previously summarised several decades of research in the AGC, linking the zircon and whole rock geochemical datasets, and have formulated a tectonic model for these rocks based on those datasets (Supplementary Information; Reimink et al., 2019a). The zircons in 4.0-3.75 Ga AGC rocks show a trend towards decreasing $\varepsilon_{\mathrm{Hf}}$ values with time. In combination with whole rock compositional data, we interpret the $\varepsilon_{\mathrm{Hf}}$ trend to be a result of crustal magma generation by repeated, closed system melting of an ancient, long-lived mafic protocrustal nucleus at $<\sim 30 \mathrm{~km}$ depth, possibly in an oceanic plateau-like environment. AGC magmas produced after $\sim 3.6$ Ga (Fig. 1) show a distinct break in the trend to more negative $\varepsilon_{\mathrm{Hf}}$ values, instead displaying a broad range from juvenile values $(+0.3)$ to those indicating contamination of magmas by older crust (-9.6). These Hf isotope data, along with other geochemical and isotopic data for these rocks, are interpreted to reflect a transition to a mobile-lid system, which brought young, surface-derived mafic crust to depths of melting beneath the evolving plateau. Partial melting of this mafic crust produced a pulse of felsic magmas with juvenile $\varepsilon_{\mathrm{Hf}}$ values that mixed with older extant crust in a tectonic setting broadly analogous to modern subduction systems. Continuation of this process formed the more extensive Slave craton basement east of the AGC (Reimink et al., 2019b).

In many cratons, detrital zircons found in Archean sedimentary sequences deposited on top of older crustal nuclei are the only extant records of evolved crust older than $3.6 \mathrm{Ga}$ (Fig. 1). Analysis of these detrital suites are poorly mixed, thus preserving a high degree of regional variation, indicating limited sediment transport distance and restricted provenance (e.g., Sircombe et al., 2001). This in turn suggests that the preserved continental detrital zircon suites represent erosion of several distinct, isolated terranes rather than of just one or two formerly contiguous terranes. Our compilation includes zircons of magmatic and detrital origins, likely providing a more complete global view of Archean processes.

The Slave craton can be used as a comparative framework to interpret the Hf isotope signatures of the global zircon archive. Notably, detrital zircons from the Slave craton sedimentary cover sequence exhibit similar $\varepsilon_{\mathrm{Hf}}$-time trends as zircons recovered from the meta-igneous rocks of the Slave craton. This validates the use of detrital zircon suites for determining the geochemical character of their source rocks. Detrital and xenocrystic zircons (Fig. 1) from the Yilgarn, Singhbhum, Pilbara, Rae, W. Superior, Limpopo, and Wyoming cratons span the age range of from 4.3-3.0 Ga. Initial $\varepsilon_{\mathrm{Hf}}$ values of the 4.3-3.8 Ga zircon record are mostly negative and generally decrease with time. In contrast, between $\sim 3.8-3.6 \mathrm{Ga}, \varepsilon_{\mathrm{Hf}}$ shifts to higher values in each terrane, requiring input from a juvenile source. This results in a bimodal distribution in $\varepsilon_{\mathrm{Hf}}$ probability density when zircon $\varepsilon_{\mathrm{Hf}}$ values are binned by age (Fig. 2). These changes are also statistically significant, as shown by change-point analysis and moving averages (Supplementary Information). Occurring in every terrane and closely matching the $\mathrm{Hf}$ isotope evolution trends of the Slave craton, we suggest that this isotopic shift represents a global transition from crustal differentiation processes dominated by in situ reworking of older crust to those characterised by significant input of more juvenile crust.

The similarity of Hf isotope trends between the Slave record and the worldwide Hadean-Eoarchean detrital zircon record suggests that the processes recorded in the Slave craton were operating globally (Figs. 1, 2). The consistently negative $\varepsilon_{\mathrm{Hf}}$ values of Hadean detrital zircons indicate reworking of older mafic material $\left({ }^{176} \mathrm{Lu} /{ }^{177} \mathrm{Hf} 0.022-0.015\right.$; Blichert-Toft and Albarède, 2008; Kemp et al., 2010), which we propose reflects episodic shallow-level melting of an extensive and persistent stagnant mafic lid (Fig. 3). Mafic crustal reworking may have been focused in areas where the mafic protocrust was locally thickened via plume-like eruptions in a 'heat-pipe' regime (Moore and Webb, 2013), where heat is transported out of the mantle by volcanism from a restricted source area through an unbroken, stagnant lithosphere. Later in the Eoarchean $(\sim 3.8-3.6 \mathrm{Ga})$, the widespread shift to higher $\varepsilon_{\mathrm{Hf}}$ values likely occurred in response to a mobile-lid tectonic regime that melted surface-derived juvenile mantle (Fig. 3).

Rocks in SW Greenland-Labrador and northern Quebec have near-zero zircon $\varepsilon_{\mathrm{Hf}}$ at 3.7-3.9 Ga (e.g., Næraa et al., 2012; O'Neil et al., 2013). No pre-3.94 Ga zircons have been found at either location, suggesting that felsic crust production in these terranes only began after $\sim 3.9$ Ga coinciding with the localised onset of the mobile-lid regime. Indeed, a subduction environment has been suggested to explain the lithologies and geochemistry of the Isua belt at $\sim 3.8 \mathrm{Ga}$ (e.g., Friend and Nutman, 2010). There is also evidence for reworking of Hadean mafic crust to form Eoarchean felsic rocks at both of these locations (e.g., Kamber, 2007; O'Neil et al., 2013). Either of these interpretations is consistent with a Hadean stagnant-lid regime prior to crustal production and preservation in the SW Greenland and northern Quebec.

Although paired zircon Hf-O isotope signatures are commonly used to infer tectonic regime changes (e.g., Dhuime et al., 2012), in the case we address here, the O isotope system would not be sensitive to a shift between stagnant- and mobile-lid tectonics as both regimes largely involve direct remelting of basaltic source rocks. Heavy zircon $\delta^{18} \mathrm{O}$ values most distinctly track weathered sedimentary input to the magmatic system, whereas partial melting of mafic crust hydrated by surficial waters will leave a more subdued isotopic imprint. Notably, there would be no expected difference in oxygen isotope composition between melts of long-lived mafic protocrust and melts of juvenile chondritic protocrust recycled in a mobile-lid regime. The lack of $\mathrm{O}$ isotope sensitivity within the processes of interest is shown by the fact that locations with substantial zircon $O$ isotope datasets, such as the Jack Hills region, are indistinguishable from those found in the AGC (Reimink et al., 2020), and no significant O isotope change occurs synchronously with a substantial Hf isotope shift.

Various geochemical datasets may suggest systematic change in the net growth rate of continental crust ca. 3.0 Ga (Dhuime et al., 2012), or even 3.2 Ga (Næraa et al., 2012). These apparent changes in net crustal growth have been suggested to be the result of modern style tectonics during the Mesoarchean. Though the statistical reliability of the observed 3.0 Ga crustal growth shift is not certain (Korenaga, 2018) and other global zircon based datasets have suggested geodynamic changes and net continental growth in the Eoarchean (Iizuka 


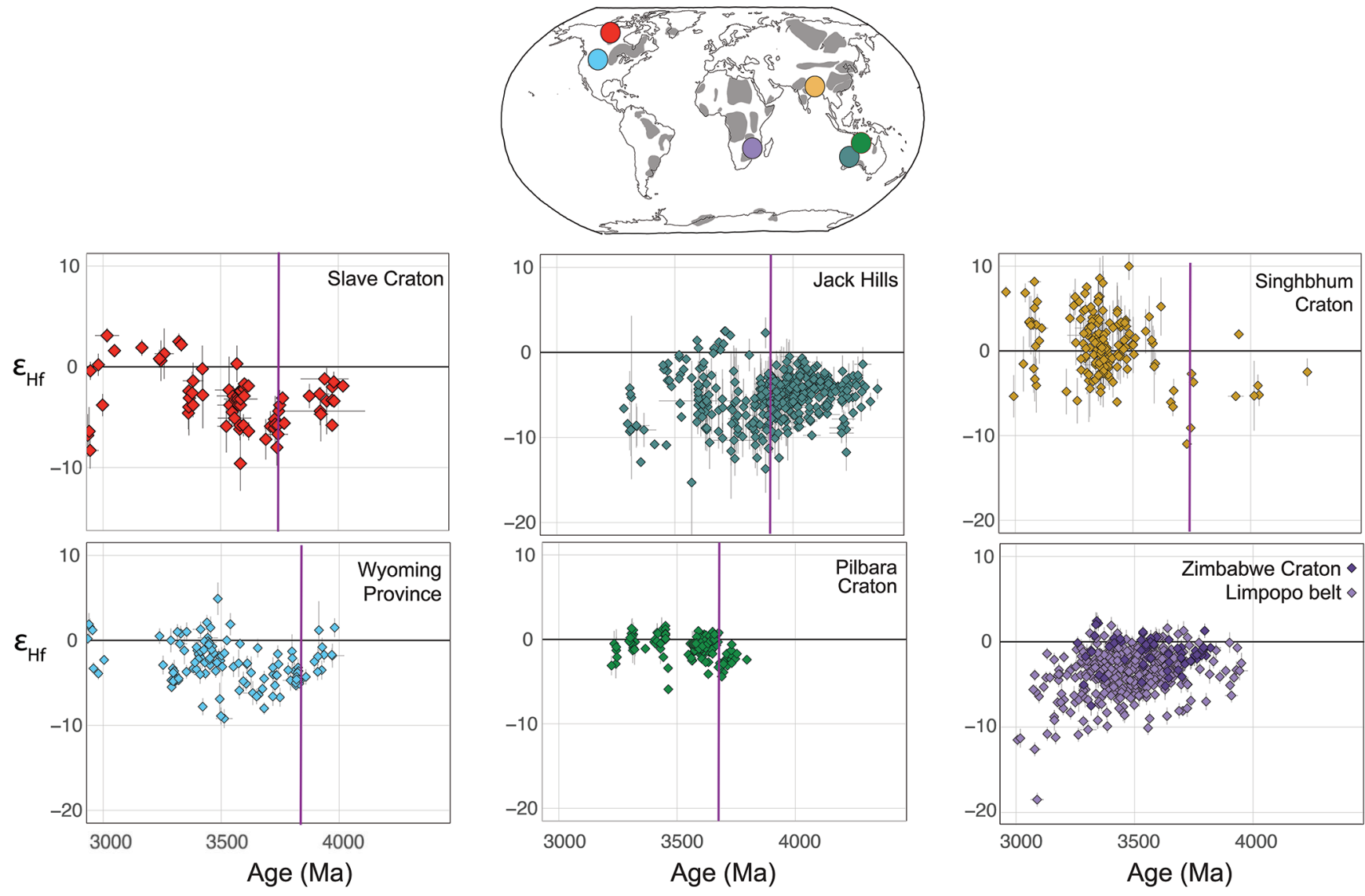

Figure 1 Zircon U-Pb-Hf isotope datasets from globally distributed Archean cratons. The purple lines show the change-point analysis inflection point shifts, which are often older than the first appearance of juvenile $\varepsilon_{\mathrm{Hf}}$ values and the loss of Hadean protocrustal signals. While the Limpopo belt does not clearly document a similar trend, detrital zircons from the Zimbabwe Craton do (Fig. S-11; Bolhar et al., 2017).

et al., 2017), our interpretations are not inconsistent with a separate tectonic change at $\sim 3.0 \mathrm{Ga}$. This dataset is diagnostic of a change from long-lived protocrust to shorter-lived crust generated in a mobile-lid setting $\sim 3.8 \mathrm{Ga}$, a change likely to result in more rapid continental crust generation than a stagnant-lid regime. This mobile-lid setting could have operated through the Archean until $3.0 \mathrm{Ga}$, when the Earth transitioned to a modern style tectonic regime (Dhuime et al., 2012) or stabilised cratonic nuclei, driving the rise of continental reworking in collisional zones.

The analysis presented here does not necessarily suggest modern style plate tectonics, but is consistent with a more general "mobile-lid tectonics," which may take many forms. A transition to "mobile-lid tectonics" is also a critical turning point in the broader differentiation of the Earth. Later $\mathrm{Nd}$ and Hf isotope records (Shirey et al., 2008; Fisher and Vervoort, 2018) are critical for parsing the evolution of the depleted mantle with time, which is reflective of crustal extraction and dependent on the volume of crust removed and preserved within continents. This suggests that more voluminous crust production via mobile-lid tectonics initiated in the Eoarchean, consistent with the onset of discernible depleted mantle signatures in the Palaeoarchean (Fisher and Vervoort, 2018).

\section{The Geodynamics of the Early Earth}

Our analysis indicates that the Eoarchean is marked by a global change in terrestrial geodynamics, most likely a transition from stagnant-lid to mobile-lid tectonics. Though mobile-lid tectonics can produce decreasing negative $\varepsilon_{\mathrm{Hf}}$ trends with time by supercontinent amalgamation, pre-3.6 Ga felsic rocks are mostly intermediate tonalites, which are not a common magma type produced in continent-continent collisions. Thus, we can rule out large scale continental reworking during this time period. A stagnant lid can potentially produce the long crustal residence times indicated by the Hf isotope trends. However, rates of volcanic burial must be less than estimated in the heat pipe model of Moore and Webb (2013); in this model Hadean resurfacing rates of $\sim 1-2 \mathrm{~mm} / \mathrm{yr}$ are needed for volcanic heat loss to balance mantle heat production by radionuclides. Such high burial rates would bury crust sufficiently deep to induce melting and felsic crust production $(30 \mathrm{~km})$ in only $15-30 \mathrm{Myr}$. This is too rapid to produce the negative $\varepsilon_{\mathrm{Hf}}$ trajectories seen in the global zircon record, implying that muted stagnant-lid volcanic fluxes may be necessary to preserve Hadean protocrust until the Eoarchean. Alternatively, a global $4.4 \mathrm{Ga}$ stagnant lid may have been melted by punctuated heat pipe volcanism (e.g., Kemp, 2018). Furthermore, crustal reworking must be confined to laterally limited regions, as a fully global process would produce felsic crust covering the entire surface, which in turn would make the eventual initiation of mobile-lid tectonics difficult (van Hunen and Moyen, 2012).

We can only speculate on how the Earth might have transitioned between stagnant- and mobile-lid modes. Cooling of the Earth could promote the formation of weak plate boundaries necessary for subduction initiation, while allowing subducting slabs to remain strong and coherent (van Hunen and van den Berg, 2008; Sizova et al., 2010). The formation of proto-continents or large oceanic plateaus could 


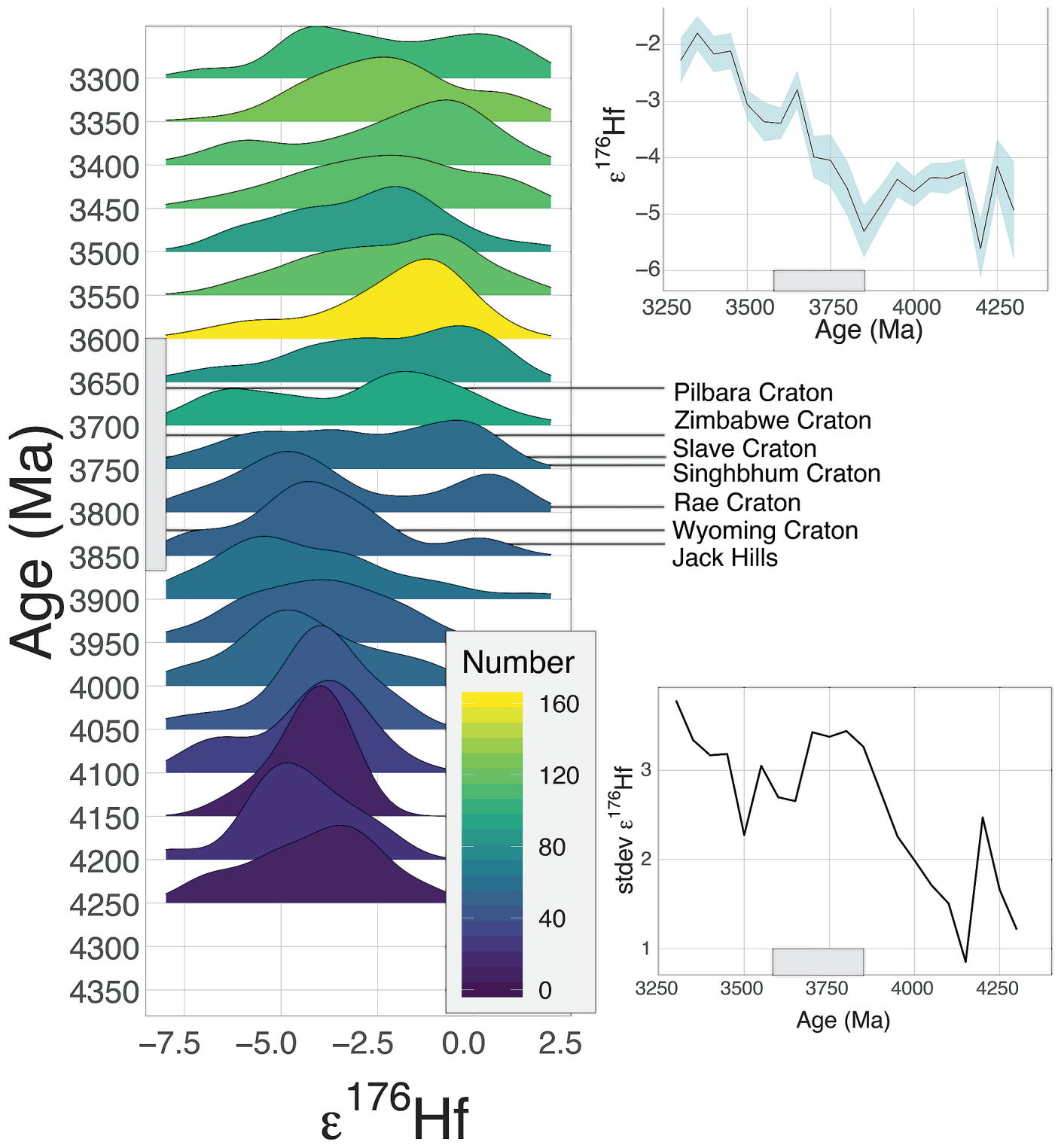

Figure 2 Stacked probability density plot of the global zircon age- $\varepsilon_{\mathrm{Hf}}$ compilation, with 50 Myr age bins. Colours indicate $n$ for each bin. The timing of change-point shifts for cratons are labeled. The upper inset shows the moving average and 2 s.e. within this population; the lower shows the moving standard deviation.

also focus stresses and initiate subduction at their margins (Nair and Chacko, 2008; Gerya et al., 2015). However, given our incomplete understanding of the lithospheric rheology responsible for the operation of modern plate tectonics, geodynamic predictions for the early Earth remain highly uncertain (Foley, 2018). The establishment of modern plate tectonics may have been a multi-stage process, with a transitional regime of subduction initiation and failure en route to the stabilisation of continuous subduction ( $\mathrm{O}^{\prime}$ Neill et al., 2018).

Zircon Hf isotope data indicate that the transition from strongly negative to more juvenile $\varepsilon_{\mathrm{Hf}}$ values occurred at slightly different times in various cratons but within a $200 \mathrm{Myr}$ period globally from $\sim 3.8-3.6$ Ga (Figs. 1,2). This constraint could be important for a general understanding of the transition between stagnant- and mobile-lid regimes during the Archean, as different mechanisms will result in a variation in the predicted timespan for this global change. For instance, regime transformation is unlikely to be due to a global mantle overturn event, which would produce a geographically widespread change over a shorter time interval. Additionally, recent modelling results indicate that it is geodynamically plausible for different regions of the Earth to experience the onset of mobile-lid tectonics at different times (Capitanio et al., 2019).

The shift to a mobile-lid tectonic regime likely produced deeper volatile cycling by subducting plates. Changes in volatile recycling rates to the mantle will have resulted in compositional changes to the atmosphere and hydrosphere with dramatic implications for terrestrial habitability. Therefore, this tectonic shift in the early Archean may have ushered Earth's surface environs into a habitable regime with more efficient volatile recycling, promoting the sustained evolution of complex life. Future work should focus on finer resolution geodynamic models to explain the timing and nature of a transition from stagnant- to mobile-lid tectonics and a more precise accounting of the onset of juvenile magmatism in different locations. Our compilation suggests a substantial geodynamic change in the Eoarchean, which would have increased continental crust growth rates. This change may explain the lack of significant volumes of continental crust preserved on Earth prior to $3.9 \mathrm{Ga}$. 

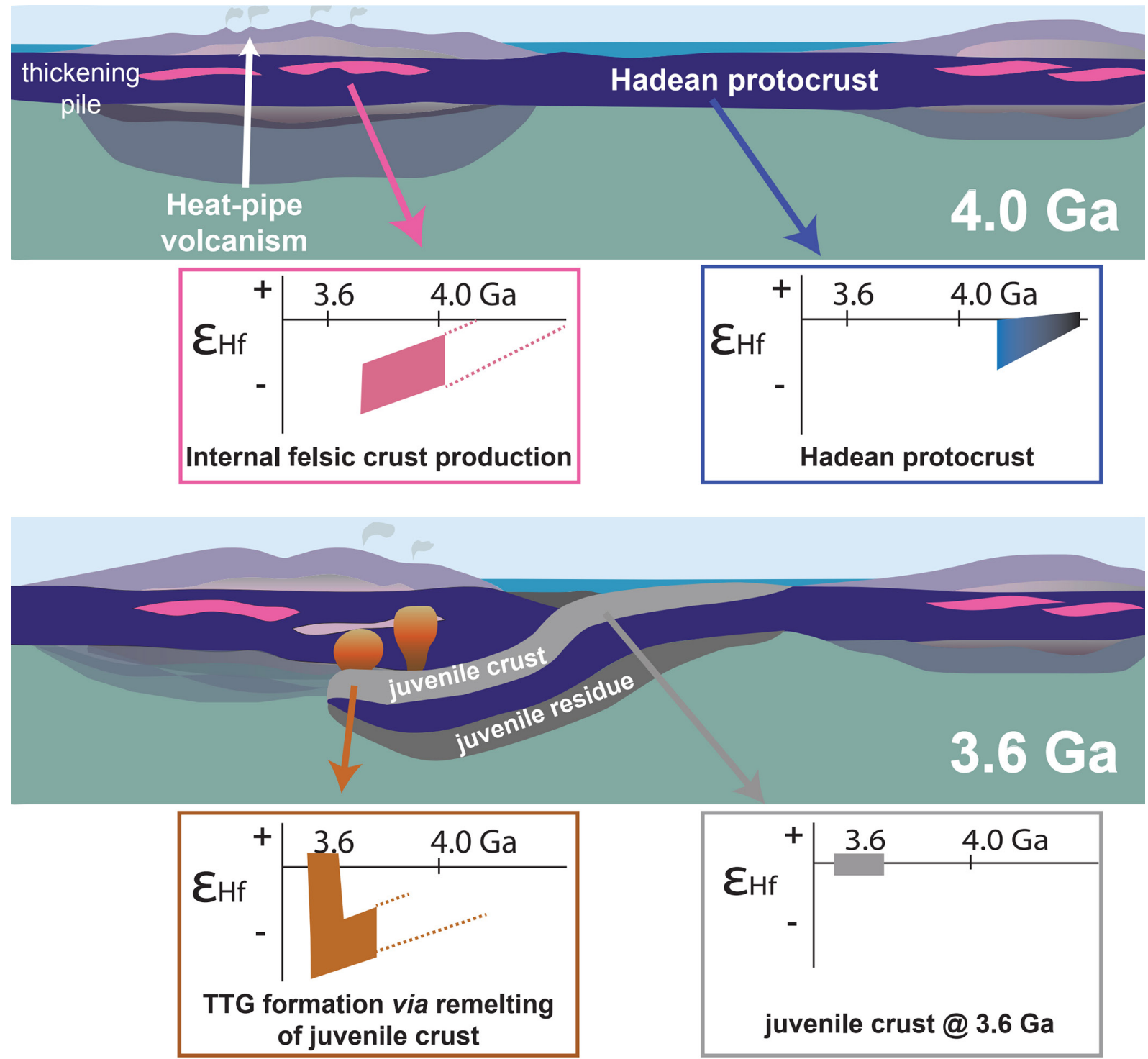

Figure 3 Schematic of global crust formation at $\sim 4.0$ and $\sim 3.6 \mathrm{Ga}$; insets depict expected $\mathrm{Hf}$ isotope signatures of magmas.

\section{Acknowledgements}

We thank Richard Carlson, Joshua Davies, Jonathan Tucker, Joyce Sim, Lara Wagner, and Tim Jones for fruitful discussions or comments on earlier versions of this manuscript. We would like to thank Tony Kemp and one anonymous reviewer for insights that improved this manuscript, Klaus Mezger for comments on an earlier version of this manuscript, and Maud Boyet for editorial handling. This project was in part supported by a Carnegie Fellowship (JRR), and NSERC funds (TC and DGP). AB thanks the Simons Foundation Collaboration on the Origins of Life for support while at Yale University.

Editor: Maud Boyet

\section{Author Contributions}

$\mathrm{AB}$ and JRR formulated the idea and compiled the data. All authors aided in data interpretation and manuscript preparation. Competing interests: The authors declare no competing interests.

\section{Additional Information}

Supplementary Information accompanies this letter at http:// www.geochemicalperspectivesletters.org/article2015.

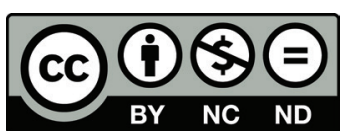

This work is distributed under the Creative Commons Attribution Non-Commercial No-Derivatives 4.0 License, which permits unrestricted distribution provided the original author and source are credited. The material may not be adapted (remixed, transformed or built upon) or used for commercial purposes without written permission from the author. Additional information is available at http://www.geochemicalperspectivesletters.org/ copyright-and-permissions.

Cite this letter as: Bauer, A.M., Reimink, J.R., Chacko, T., Foley, B.J., Shirey, S.B., Pearson, D.G. (2020) Hafnium isotopes in zircons document the gradual onset of mobile-lid tectonics. Geochem. Persp. Let. 14, 1-6. 


\section{References}

BLICHERT-TofT, J., AlBARÈDE, F. (2008) Hafnium isotopes in Jack Hills zircons and the formation of the Hadean crust. Earth and Planetary Science Letters 265, 686-702.

Bolhar, R., Hofmann, A., Kemp, A.I., Whitehouse, M.J., Wind, S., Kamber, B.S. (2017) Juvenile crust formation in the Zimbabwe Craton deduced from the O-Hf isotopic record of 3.8-3.1 Ga detrital zircons. Geochimica et Cosmochimica Acta 215, 432-446.

Capitanio, F.A., Nebel, O., Cawood, P.A., Weinberg, R.F., Clos, F. (2019) Lithosphere differentiation in the early Earth controls Archean tectonics. Earth and Planetary Science Letters 525, 115755

Dhuime, B., Hawkesworth, C.J., Cawood, P.A., Storey, C.D. (2012) A change in the geodynamics of continental growth 3 billion years ago. Science 335, 1334-1336.

FISHER, C.M., VERVOORT, J.D. (2018) Using the magmatic record to constrain the growth of continental crust-the Eoarchean zircon Hf record of Greenland. Earth and Planetary Science Letters 488, 79-91.

FOLEY, B.J. (2018) The dependence of planetary tectonics on mantle thermal state: applications to early Earth evolution. Philosophical Transaction of the Royal Society A: Mathematical, Physical and Engineering Sciences 376, 20170409.

Friend, C.R., Nutman, A.P. (2010) Eoarchean ophiolites? New evidence for the debate on the Isua supracrustal belt, southern West Greenland. American Journal of Science 310, 826-861.

Gerya, T.V., Stern, R.J., Baes, M., Sobolev, S.V., WhatTam, S.A. (2015) Plate tectonics on the Earth triggered by plume-induced subduction initiation. Nature 527, 221-225.

Iizuka, T., Yamaguchi, T., ITANO, K., HibiYA, Y., SuZUKI, K. (2017) What Hf-isotopes in zircon tell us about crust-mantle evolution. Lithos 274 304-327.

KAMBER, B.S. (2007) The Enigma of the Terrestrial Protocrust: Evidence for It Former Existence and the Importance of Its Complete Disappearance. In: Van Kranendonk, M.J., Bennett, V.C., Smithies, R.H. (Eds.) Earth's Oldest Rocks. First Edition, Elsevier, Cambridge, 75-89.

KEMP, A. (2018) Early earth geodynamics: cross examining the geological testimony. Philosophical Transactions of the Royal Society A: Mathematical Physical and Engineering Sciences 376, 20180169.

Kemp, A.I.S., Wilde, S.A., Hawkesworth, C.J., COATH, C.D., Nemchin, A., Pidgeon, R.T., Vervoort, J.D., DuFrane, S.A. (2010) Hadean crustal evolution revisited: new constraints from $\mathrm{Pb}-\mathrm{Hf}$ isotope systematics of the Jack Hills zircons. Earth and Planetary Science Letters 296, 45-56.

KorenaGA, J. (2018) Estimating the formation age distribution of continental crust by unmixing zircon ages. Earth and Planetary Science Letters 482, 388-395.

Moore, W.B., WebB, A.A.G. (2013) Heat-pipe Earth. Nature 501, 501-505.

NAIR, R., CHАСКО, T. (2008) Role of oceanic plateaus in the initiation of subduction and origin of continental crust. Geology 36, 583-586.

NÆraA, T., Scherstén, A., Rosing, M.T., Kemp, A.I.S., Hoffmann, J.E., KoKfelt, T.F., Whitehouse, M.J. (2012) Hafnium isotope evidence for a transition in the dynamics of continental growth 3.2 Gyr ago. Nature 485, 627-630.

O’Neil, J., Boyet, M., Carlson, R.W., Paquette, J.-L. (2013) Half a billion years of reworking of Hadean mafic crust to produce the Nuvvuagittuq Eoarchean felsic crust. Earth and Planetary Science Letters 379, 13-25.

O'Neill, C., Turner, S., Rushmer, T. (2018) The inception of plate tectonics: a record of failure Philosophical Transactions of the Royal Society A: Mathematical, Physical and Engineering Sciences 376, 20170414.

Reimink, J.R., Chacko, T., Stern, R.A., Heaman, L.M. (2014). Earth's earliest evolved crust generated in an Iceland-like setting. Nature Geoscience 7, 529-533.

REIMINK, J.R., BAUER, A.M., CHACKO, T. (2019a) The Acasta Gneiss Complex In: Van Kranendonk, M.J., Bennett, V.C., Hoffmann, J.E. (Eds.) Earth's Oldest Rocks. Second Edition, Elsevier, Cambridge, 329-347.

Reimink, J.R., Pearson, D.G., Shirey, S.B., Carlson, R.W., Ketchum, J.W.F. (2019b) Onset of new, progressive crustal growth in the central Slave craton at $3.55 \mathrm{Ga}$. Geochemical Perspectives Letters 10, 8-13.

ReIminK, J.R., DAviES, J.H., BAUER, A.M., CHACKO, T. (2020) A comparison between zircons from the Acasta Gneiss Complex and the Jack Hills region. Earth and Planetary Science Letters 531, 115975.

Shirey, S.B., Kamber, B.S., Whitehouse, M.J., Mueller, P.A., Basu, A.R. (2008) A review of the isotopic and trace element evidence fo mantle and crustal processes in the Hadean and Archean. GSA Special Papers $440,1-29$
SiRCOMBE, K.N., BleEKER, W., SteRn, R.A. (2001) Detrital zircon geochronology and grain-size analysis of a $2800 \mathrm{Ma}$ Mesoarchean proto-cratonic cover succession, Slave Province, Canada. Earth and Planetary Science Letters 189, 207-220.

Sizova, E., Gerya, T., Brown, M., Perchuk, L.L. (2010) Subduction styles in the Precambrian: Insight from numerical experiments. Lithos 116 , 209-229.

VAN HUNEN, J., VAN DEN BERG, A.P. (2008) Plate tectonics on the early Earth: Limitations imposed by strength and buoyancy of subducted lithosphere. Lithos 103, 217-235.

van Hunen, J., Moyen, J.-F. (2012) Archean Subduction: Fact or Fiction? Annual Review of Earth and Planetary Sciences 40, 195-219.

Van Kranendonk, M.J., Smithies, R.H., Griffin, W.L., Huston, D.L., Hickman, A.H., Champion, D.C., Anhaeusser, C.R., Pirajno, F. (2015) Making it thick: a volcanic-plateau origin of Palaeoarchean continental lithosphere of the Pilbara and Kaapvaal cratons. Geological Society, London, Special Publications 389, 83-111. 